\title{
Numerical comparison between the thermo-structural behavior of steel and partially encased steel and concrete composite columns in fire
}

\section{Comparação numérica entre o comportamento termoestrutural de pilares de aço e mistos de aço e concreto parcialmente revestidos em situação de incêndio}

Y. S. SIMÕES a yaghosimoes@usp.br

F. M. ROCHA a fabio.rocha@usp.br

J. MUNAIAR NETO a jmunaiar@sc.usp.br

\begin{abstract}
The bare steel structural members have a low fire resistance. However, in steel and concrete composite members, the concrete encasement, besides the contribution to the stiffness of the whole system, reduces the amount of heat that reaches the steel profile, increasing the its fire resistance. The aim of this paper is to conduct a numerical study on the behavior of steel and steel and concrete composite columns in fire, in order to compare their performance based on the variation of parameters such as the stiffness of the surrounding structure, geometric imperfection and load ratio. It has been found that, in general, the intensity of the geometric imperfection and stiffness of the surrounding structure does not affect the fire resistance of steel and composite columns. However, the stiffness of the surrounding structure raised the maximum value of the restraining forces generate throughout the heating. Regarding the load ratio, when increased, the fire resistance and critical temperature decreased.
\end{abstract}

Keywords: steel and concrete composite columns, steel columns, numerical study, fire, fire resistence.

\section{Resumo}

Os elementos construtivos de aço sem proteção possuem baixa resistência ao fogo. Apesar disso, nos elementos mistos de aço e concreto, o revestimento de concreto, além da contribuição de rigidez para o sistema, reduz a quantidade de calor que chega ao elemento de aço aumentando assim a sua resistência ao fogo. Diante disso, o artigo tem como objetivo realizar um estudo numérico acerca do comportamento de pilares isolados de aço e mistos de aço e concreto em elevadas temperaturas, visando comparar o desempenho dos mesmos a partir da variação de parâmetros como rigidez da estrutura circundante, imperfeição geométrica inicial e fator de carga. Foi constatado que, em geral, a intensidade da imperfeição geométrica e da rigidez da estrutura circundante não afeta a resistência ao fogo de pilares de aço. Entretanto, a rigidez da estrutura circundante elevou o valor máximo das forças de restrição geradas. Em relação ao nível de carga, quando aumentado, diminuiu o tempo e a temperatura críticos.

Palavras-chave: pilares mistos de aço e concreto, pilares de aço, estudo numérico, incêndio, resistência ao fogo.

Universidade de São Paulo, Departamento de Engenharia de Estruturas, Escola de Engenharia de São Carlos, São Carlos, SP, Brasil. 


\section{Introduction}

Steel and concrete are the main materials used in civil construction. Regarding the fire action, steel has a poor behavior when not protected, since it has a high thermal conductivity and it forms profiles which parts have reduced thicknesses. The sum of the factors described leads to a faster section heating, also accelerating the degradation of its mechanical properties (stiffness and tensile and compressive strength).

The steel behavior concerning fire can be improved by applying to it fire protection encasement or by associating it with other materials that have a better performance at high temperatures. The high cost and the aesthetic interference that the protective materials can cause in the structural element are some of the key problems in the use of this solution.

Concrete encasement on steel profiles is a good option to be used to ensure greater strength of the structural elements at room temperature and also in a fire situation. By forming stronger structural elements and by the lower thermal conductivity of the material, concrete structures take longer to heat in comparison to the steel structures. In view of the presented features, composite structures are increasingly being used in the construction of multi-floor buildings. In this structural conception, concrete increases the structure bearing capacity and acts as a steel profile encasement, protecting it against fire and corrosion actions. Steel, on the other hand, also improves concrete behavior at high temperatures, in order to reduce the displacement effect and its cracking.

In Brazil, the subject is approached by the Brazilian Association of Technical Standards (ABNT) through the Brazilian Standard (NBR) 14323 [1] which basically follows the principles of European standards, EUROCODE 3 and 4 Part 1-2 [2, 3]. The standard script presents a simplified design method for isolated columns taking into account only the degradation of the mechanical properties of the materials with the temperature increase. However, according to Bubach [4], in real fire situations, in addition to the mentioned reduction, the interaction between the structural element and the surrounding structure must be considered, which may compromise the application of the referenced method.

The columns are part of a global structure, so that they interact with the beams or slabs, which may be on top of them. Therefore, during a fire, the column naturally tends to deform, but the rest of the structure imposes thermal restraints on this deformation, which promotes the presence of additional stresses on the isolated columns that can affect their stability, modifying the element fire resistance [4].

There are two types of thermal restraints, the axial restraint, which imposes a certain effort to the longitudinal deformation of the column, causing the increase of its axial forces, and the rotational restraint, responsible for partially obstructing the rotation at the column ends and generating bending moments. The scientific community states that both restraints have opposite effects on the fire resistance of 4-face heated columns, so that the axial restraint acts in a way to decrease it, and the rotational one increases it [1, 5, 7, 8, 9, 11].

Neves [5] carried out a detailed numerical study, using the ZWAN computational code, regarding the surrounding structure influence, the applied load eccentricity and the slenderness on the behavior of steel columns in a fire situation. From the restraining forces behavior, the author defined the concept of steel columns fire resistance as the moment when, after the internal forces increase, the column returns to the observed loading level prior to heating. This moment is called critical time and the temperature associated with it is called the critical temperature. This concept will be used in the present work.

Aasen [6] presents an experimental analysis of steel columns in a fire situation, considering thermal restraints in their ends. The aim of this work was to evaluate the influence of axial and rotational restraints on the fire resistance of these structural elements. Similarly, Ali et al. [7] and Ali and O'Connor [8] developed an experimental program to study the parameters mentioned above, including load ratio variation and structural element slenderness (only in the first study). Neves et al. [9] created a numerical model, from the FINEFIRE computational code, in order to determine a simplified methodology capable of accounting for thermal restriction effect in determining the critical temperature value of steel columns that had been tested without restriction at their ends. Therefore, a parametric analysis was performed with the variation of the following parameters: cross-section, slenderness indexes and load ratio.

Correia and Rodrigues [10] proposed a new structure for experimental tests of columns in a fire situation, so that the structural element was inserted into a three-dimensional restraining frame capable of representing a real structural system. The study was based on the variation of the same parameters evaluated in Neves et al. [9]. The following year, Correia et al. [11] used the experimental data of the developed tests and carried out a numerical research with the purpose of proposing a simplified method to determine the fire resistance of steel columns in a fire situation with thermal deformation restrictions.

In the same research path, Bubach [4] analyzed the behavior of steel columns with axial and rotational restraints, acting individually and simultaneously, from a numerical modelling. Subsequently, the numerical results were compared with those provided by the Brazilian standard ABNT NBR 14323 [1].

The presented studies reached similar conclusions, noting the negative effect of the axial restriction and positive effect of the rotational restriction in the fire resistance of the column. In addition, it was possible to conclude that the increase in load ratio caused a sudden drop in the intensity of the generated constraining forces and the critical temperature. In relation to the slenderness, in general, its increase resulted in the fire resistance reduction.

Most of the researches carried out worldwide refer to steel and concrete composite columns, just a few considered the partially encased columns.

Huang et al. [12] tested isolated partially encased columns considering only axial restriction (with varying levels) at the ends. The authors concluded that their collapse occurred due to global instability and that the axial restriction increased the compressive force, which reduced their fire resistance. Another phenomenon that also helped in this decrease was the concrete displacement. The following year, these authors [13] developed another numerical modelling, this time, in order to evaluate the influence of the applied load ratio on the composite column and the cross-section dimensions. The results indicate that, for high load ratios, sections with small dimensions present low fire resistance. 


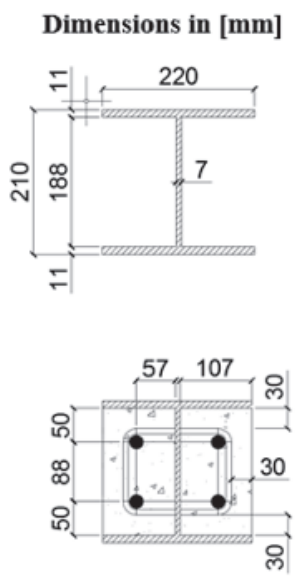

(a)

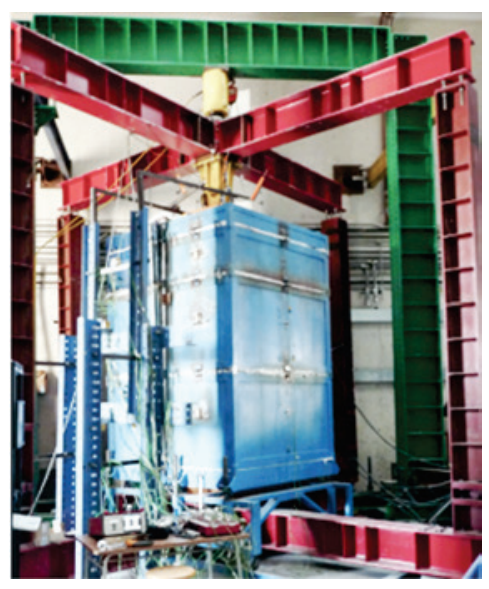

(b)
Figure 1

a) Geometric characteristics of the cross-sections of the studied columns; b) Test system (Rocha [18])

Correia and Rodrigues [14], using the same test structure presented in Correia and Rodrigues [10], tested steel columns partially encased with concrete, with axial and rotational constraints (different intensities) at their ends subjected to high temperatures, also varying the load ratio and column slenderness. The main finding, in addition to those already described, was the increase in fire resistance compared to steel columns.

Ellobody [15] performed a numerical study of partially encased fireexposed columns changing the load ratios, axial stiffness, crosssectional dimensions and the aggregate type used in the concrete. The study found that the composite columns without axial restraint showed a sudden collapse, unlike those with thermal restraint that presented in the "constraint force $x$ time" graph, a softer drop.

Han et al. [16, 17], through experimental tests and numerical analysis, described the behavior of encased composite columns under fire action. The first study [16] proposes a simplified method, based on parametric analysis performed by numerical modelling, to determine the columns fire resistance, while the second article [17] increased the knowledge regarding the post-fire behavior of these structural elements.

The works presented above considered in its analysis the behavior of isolated steel columns and steel and concrete composite columns separately. Therefore, in order to identify the difference in structural performance between these elements, a set of numerical analysis was developed to evaluate the benefits of concrete in a fire situation. Other analysis with the validated model were also developed, aiming at analyzing parameters such as the influence

\section{Table 1}

Theoretical load capacity for the columns used

\begin{tabular}{|c|c|}
\hline Profile type & (kN) \\
\hline HEA 220 - steel profile & 1560 \\
\hline HEA 220 - composite column & 2610 \\
\hline Source: Rocha [18] (adapted) \\
\hline
\end{tabular}

of the axial restraint level, the applied load ratio and the intensity of the initial geometric imperfection in the fire resistance of steel and steel and concrete composite columns.

\section{Reference experimental model}

The development of a consistent numerical modelling is based on a detailed study of the experimental test used for its validation. To validate the numerical models, the results of the experiments described in Rocha [18] and carried out in the Laboratory of Testing Materials and Structures of the University of Coimbra were adopted. This experimental work focused on the study of steel only and steel and concrete composite columns embedded on walls, still, tests without walls were also performed.

The experimental program was defined in order to evaluate the following parameters: columns slenderness, wall thickness, profile position in relation to walls, influence of concrete acting in conjunction with steel profiles and load ratio. Considering the tests on isolated and inserted-into-walls columns, a total of 12 prototypes were carried out at elevated temperatures. The numerical study that will be approached in this article used only the results for the isolated columns (no walls) of Rocha [18].

Highlighting the columns used in this work, the HEA 220 steel profile with $2940 \mathrm{~mm}$ in height was used. As a boundary condition, square plates measuring $450 \times 450 \times 30 \mathrm{~mm}$ in thickness were considered at the element ends, resulting in a column with a total height equal to $3000 \mathrm{~mm}$. For the composite columns, concrete of class $\mathrm{C} 30 / 37$ placed between the flanges was used. Besides, the concrete was longitudinally reinforced with $20 \mathrm{~mm}$ diameter bars, CA50 type, as well as transversely with $8 \mathrm{~mm}$ diameter stirrups and $15 \mathrm{~cm}$ spacing. The cross-sectional dimensions used are shown schematically in Figure 1a.

For carrying out the tests considering elevated temperatures, the cross-section load capacity was determined so that the column was loaded as a portion of this value. The load applied in relation to the column load capacity is called load ratio or level. This situation will represent the load on which a building column will be subjected in case of fire. From the calculation methodologies provided by EUROCODE 3 and 4 [2, 3], Table 1 shows the theoretical values used. As regards the test procedures, the columns were initially loaded at a $30 \%$ load ratio of their strength capacity (Table 1 ), then they were inserted into a three-dimensional restraint system and then heated in a vertical electric furnace (Figure 1b). This furnace was a modular type, composed of three modules with individual power supply, two modules with $1 \mathrm{~m}$ in height and the other one with $0.5 \mathrm{~m}$. Therefore, only $2.5 \mathrm{~m}$ from the column were heated. The furnace openings through which the column was to be tested were thermally insulated with ceramic blankets to prevent heat loss to the environment and to prevent the furnace from heating.

Figures $2 \mathrm{a}$ and $2 \mathrm{~b}$ show a schematic cross-sectional representation of each of the study field columns. It shows the positions of the thermocouples located in the experimental tests, responsible for measuring the temperature. They are presented by the terminology TX.Y, where $X$ indicates the column section along its length being studied, while $Y$ indicates the measurement point numbering. It is further noted that temperatures were measured in five sections, as shown in Figure 2c. In spite of this, the results presentation and 


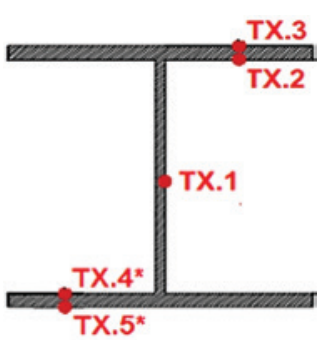

(a)

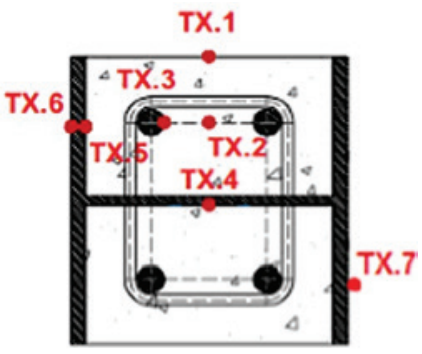

(b)

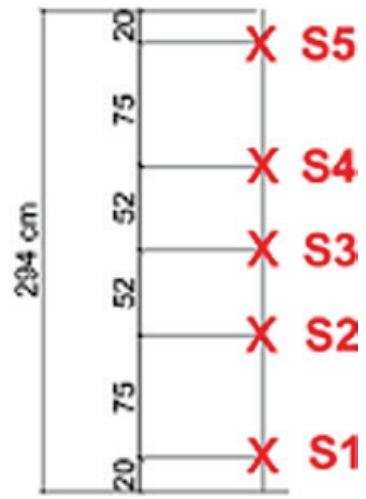

(c)

\section{Figure 2}

Instrumentation of the experimental test: a) Steel column; b) Composite column; c) Indication of the sections in which the temperatures were measured (Rocha [18])

the validation of the proposed models will be done with reference to section 3 (central), since it presented the highest temperature among the others, and for that reason the greatest degradation of its mechanical properties.

\section{Proposed numerical models}

For the numerical modelling, the ABAQUS computational code was used, which has the Finite Element Method as the basic formulation for solving engineering problems, which in turn provides a range of finite elements that can be used to build the models of interest. After analysis of processing time, results and compatibility between the different types of elements, shell elements were adopted for the steel profile, solid element for the concrete and beam element for the reinforcements.

Each of the developed numerical analysis consisted of three steps performed in sequence. The first one, called thermal analysis, is responsible for determining the temperature range obtained in the experimental test during the entire heating time. The second one is the insertion of the initial geometric imperfections as a displacement in the middle of the column span. And in the last step, called thermo-structural analysis, the imperfect structural element is loaded and gradually receives the previously determined thermal field aiming to represent the behavior of the actual column in a fire situation. In this step, the development of the axial forces and displacements during the heating is analyzed.

Table 2 indicates the nomenclature adopted by the computational code for the finite elements used in the thermal and thermo-structural modelling.

\subsection{Boundary conditions and materials properties}

ABAQUS adopts the principle of energy conservation to perform its thermal analysis, using the thermal equilibrium equations.

\section{Table 2}

Finite element nomenclature used in thermal and structural models

\begin{tabular}{|c|c|c|}
\hline $\begin{array}{c}\text { Structural element } \\
\text { component }\end{array}$ & $\begin{array}{c}\text { Finite element: } \\
\text { thermal model }\end{array}$ & $\begin{array}{c}\text { Finite element: } \\
\text { structural model }\end{array}$ \\
\hline Steel profile & DS4 & S4R \\
\hline Concrete & C3D8 & C3D8R \\
\hline Reinforcement & DC1D2 & T3D2 \\
\hline
\end{tabular}

Regarding the type of analysis, the transient analysis in which the thermal properties of the materials and the temperature distribution vary over time is assumed in this research. The boundary conditions required to perform a thermal analysis refer to the heat transfer mechanisms.

For the convection and radiation study, the convection coefficients $\left(\alpha_{c}\right)$ for the first mechanism, as well as the material emissivity $(\varepsilon)$ and the Stefan-Boltzmann constant $\left(5,67 \times 10^{-8} \mathrm{~W} / \mathrm{m}^{2} \mathrm{~K}^{4}\right)$ for the second are inserted. Heat conduction is considered as part of the numerical model of parameters related to the section material itself, such as density, thermal conductivity and specific heat. The heating curves used for the model validation were those obtained in the three furnace modules extracted from the experimental tests presented in Rocha [18], since they were different from the standard fire curve of the International Organization for Standardization (ISO) 834 [19] recommended for fire tests. The difference between the curves obtained in the experimental tests and that corresponding to ISO 834 [19] is shown in Figure 3. It is observed that the maximum distinction between them occurs in the first 20 minutes, with the largest variation found being equivalent to $200^{\circ} \mathrm{C}$, which guarantees that the experimental curves are outside the tolerance limit established by ISO 834 [19] for according to the referred standard a divergence greater than $100^{\circ} \mathrm{C}$ between the heating and the standard fire curves is not allowed after 10 minutes of exposure. The determination of the values of the mentioned parameters was initially based on those provided by ABNT NBR 14323 [1], i.e.

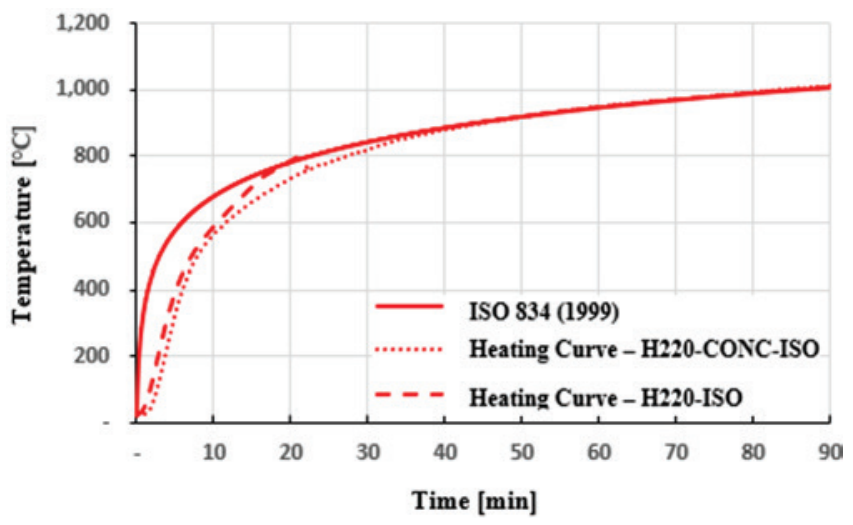

Figure 3

Comparison between the experimental curves and the standard fire curve ISO 834 [19] 
$\alpha_{\mathrm{c}}=25 \mathrm{~W} / \mathrm{m}^{2}{ }^{\circ} \mathrm{C}$ and $\varepsilon=0.7$ for the surface formed by steel and concrete. Nevertheless, during the comparison of the numerical results with the experimental ones presented in Rocha [18], it was verified that a good compatibility was not obtained, hence sensitivity tests for such parameters were necessary. Thus, the emissivity value was varied from 0.5 to 0.9 and subsequently, 0.8 was adopted as the emissivity for the steel and 0.7 for the concrete, since they gave more representative results. The change in emissivity values is justifiable because the heating situation that is obtained in an electric furnace test is different from that which will be verified in a real fire. In relation to the convection coefficient, the value provided by the standard was reasonable.

Steel and concrete properties used in thermal and thermo-structural modelling of the parametric analysis of this study, which were carried out after the model validation, followed the Brazilian standards ABNT NBR 14323 [1] for steel and ABNT NBR 15200 [20] for concrete, i.e. the convection and emissivity coefficients previously mentioned $\left(\alpha_{c}=25 \mathrm{~W} / \mathrm{m}^{2}{ }^{\circ} \mathrm{C}\right.$ e $\left.\varepsilon=0,7\right)$ were considered, as well as the curve by ISO 834 [19] for heated columns.

Regarding the mechanical properties, the steel was modelled following the von Mises yield criterion in conjunction with the voltage versus strain diagrams as a function of temperature presented in ABNT NBR 14323 [1]. However, for the reinforcement of the steel and concrete composite columns, the degradation of the mechanical properties with the temperature increase was not considered, because in the experimental test the value of this parameter was always lower or close to $400^{\circ} \mathrm{C}$, when the steel starts losing resistance. For the concrete, it was observed that by adopting the elastic properties for this material, the model was sufficient to effectively represent the thermo-structural behavior of the composite columns.

In the conception of the numerical models, the longitudinal and transverse reinforcements were considered through the embedded reinforcements command, in order to allow the interaction between concrete and reinforcements. For the steel and concrete surfaces union in the contact regions, the tie constraint function of "master-slave surfaces" type was adopted, responsible for joining the degrees of freedom between the nodes of the surfaces in contact, resulting in a situation of total interaction between the materials.

\subsection{Numerical model representation}

The proposed numerical models for steel and composite columns are shown in Figures $4 a$ and $4 b$, respectively. As can be seen, square plates were not considered, so that their final length was equal to $2.94 \mathrm{~m}$. It is also worth noting that the columns were represented horizontally to facilitate visualization.

The numerical strategy adopted for the thermo-structural representation of the columns consists of inserting a spring at the upper end of the element in order to simulate the three-dimensional restraint structure of the experimental test. Neves [5] had already stated that the structure reaction to the column heating can be compared to the action of a spring, whose stiffness depends on the physical and geometrical characteristics of the structure that surrounds the tested element. Thus, the spring will receive the axial and rotational stiffness of the restriction structure, and from a sensitivity test, values of $30 \mathrm{kN} / \mathrm{mm}$ for axial stiffness and $5000 \mathrm{kN}$.m/rad for rotational stiffness were defined.

Initially, reference nodes were created at the columns ends on which the degrees of freedom of the structural element ends were coupled. In the lower part, the RP-1 node was created and at the upper part were created the RP-2 and RP-3 nodes that receive degrees of freedom from the top of the column and represent the behavior of a spring.

The thermo-structural model development was performed in 2 phases. The first phase consisted of the column loading stage with $30 \%$ of its final load, in which the axial force in the RP-2 node was applied. Moreover, as a boundary condition, the RP-1 node was fixed as well as the displacements in the $X$ and $Y$ directions and the rotation around the $Z$ axis in the RP-2 node represented in Figure 3 , so that the other degrees of freedom could be unrestricted to display themselves. In the RP-3 node, no boundary condition was applied because during mechanical loading the upper end of the column is free to deform and the spring does not participate.

The second phase represents the column heating step and is based on the coupling between the thermal field, defined in the previous analysis, and the deformations obtained by the column loading. Therefore, the numerical model temperatures were transferred to this step, in order to simulate the structural element heating. Furthermore, the spring participation at the upper end as a

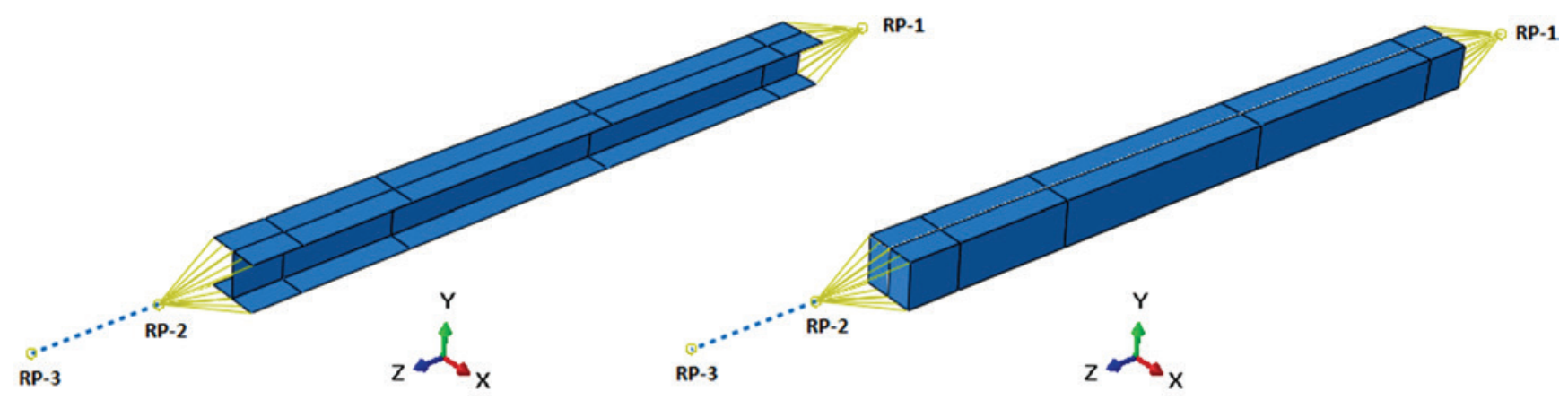

(a)

(b)

Figure 4

Modelled columns: a) H22O-ISO; b) H22O-CONC-ISO 
boundary condition for the RP-3 node was inserted so that it acts by restricting the longitudinal deformations ( $Z$ axis) and the rotations around the $X$ and $Y$ axes which in the previous step were free to deform. The numerical models were processed until the moment when the column, after presenting the axial force peak, returned to present the applied initial load, being this fire resistance criterion defined by Neves [5].

The numerical results validation process, by comparing to the experimental results presented in Rocha [18], was divided in two stages, which were applied to steel only and steel and concrete composite columns.

In the first step, thermal analysis was performed to compare if the temperatures obtained numerically showed good compatibility with those measured in the experimental tests.

The second step concerns the thermo-structural model validation, using axial displacement and relative axial force as comparison parameters between numerical and experimental results. The relative axial force is obtained by the relation between the axial force at a given heating instant and the measurement before starting the heating, thereby resulting in a dimensionless magnitude. The use of force, in relative terms, facilitates the results discussion when comparing the steel and composite columns, since the load applied in each of these cases is different.

\section{Results}

In view of the modelling strategy, presented in the previous items, the thermal and thermo-structural model for the steel only and steel and concrete composite columns were validated through the tests presented in Rocha [18] and already described in item 2.

After the validation, the models were used to perform a parametric analysis considering the ISO 834 [19] standard fire curve and the
ABNT NBR 14323 [1] resulting emissivities, taking into account the influence of factors such as the intensity of the overall imperfection in the column, the loading level and axial restriction at the ends. Validation and parametric analysis will be discussed throughout this section.

\subsection{Numerical model validation}

Starting with the thermal analysis results, the temperature variations, obtained numerically and experimentally, in the middle section of the steel and composite columns, respectively, are presented in Figures $5 a$ and $5 b$.

In the steel column case, only two reading points were used for validation, one for the web profile (T3.1) and the other one for the top flange (T3.2). As the temperature in the section is practically uniform, there is only a small temperature difference between the web and the flange, since the web has higher temperatures due to the greater slenderness and the contact area with the heat. As can be observed, the numerical temperatures are very close to the experimental measurements.

In the composite column case, shown in Figure $4 \mathrm{~b}$, most of the numerical results were well suited to the experimental ones, so that the difference between the curves was less than $10 \%$ in most cases. However, only the temperatures obtained numerically for the T3.1 reading point, for the most part of the test, result $100^{\circ} \mathrm{C}$ higher than those identified during the test. This is justified due the fact that the T3.1 temperature was obtained inside the concrete, approximately $1 \mathrm{~cm}$ from the surface in contact with the heat. Therefore, it cannot be said that the point at which the temperature was obtained numerically corresponds exactly to the test reading point, possible cause for the results difference. Nevertheless, this difference does not compromise
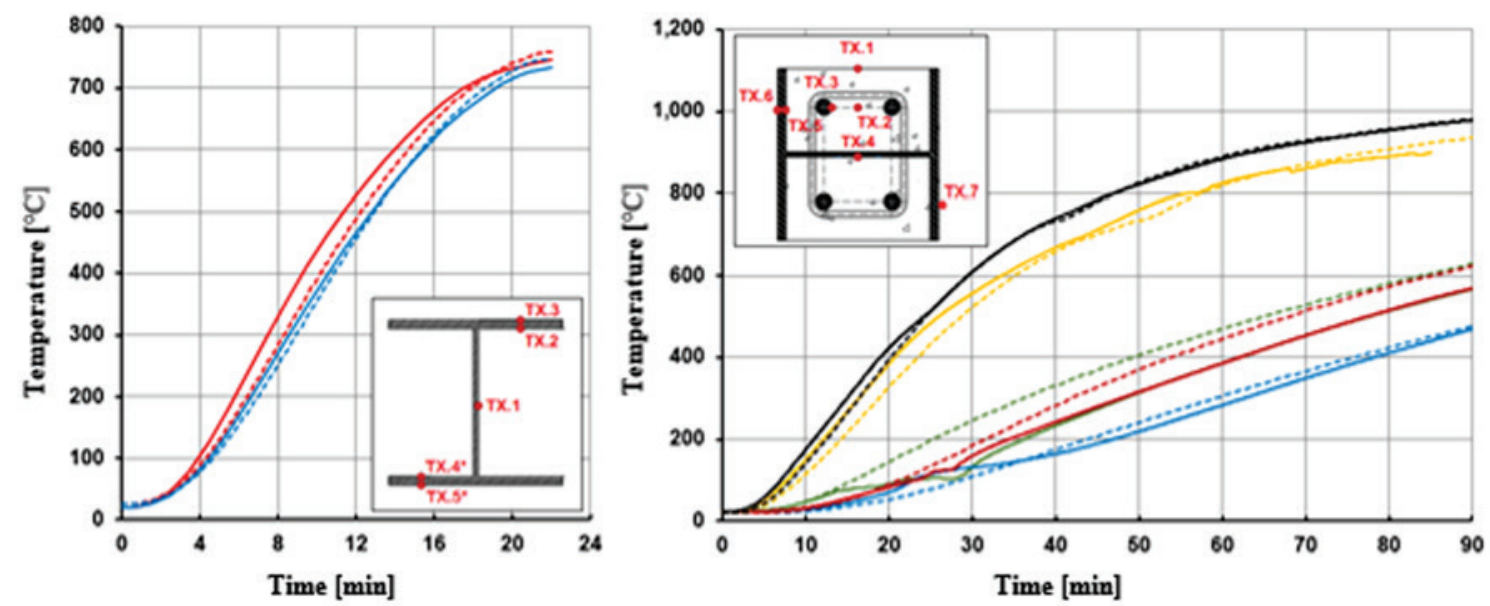

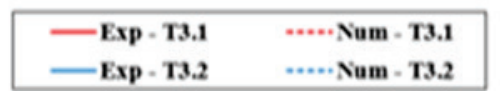

(a)

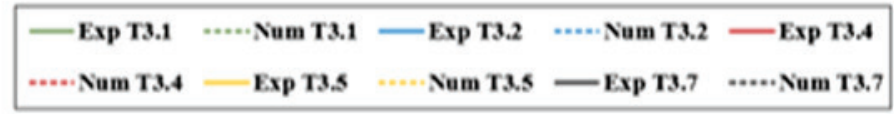

(b)

\section{Figure 5}

Comparison between the temperatures obtained in the tests and numerically for the steel (a) and composite (b) columns 
the results, since in practical terms, the resistance loss is not high for a temperature increase of $100^{\circ} \mathrm{C}$.

With the validated thermal model, we compared the thermo-structural results of the modelled columns. Figures $6 a$ and $6 \mathrm{~b}$ show the force and axial displacement development in the steel and steel and concrete composite columns, respectively.

By analyzing, firstly, the relative axial forces result for the steel columns, it is observed that the numerical results are slightly higher than the experimental ones, with the greatest difference found of $5 \%$ between the curves in their rising part. In their descending part, the difference increases to more than $10 \%$, but this is acceptable, since at that moment the column already has advanced local instability which makes numerical representation difficult. In view of the foregoing, since the force being developed in the structural element is greater in the numerical model (Figure 6a), as described previously, the displacement portion relative to compression is also higher, which results in total axial displacement of the shortest column than that obtained experimentally, around $5 \%$ in the ascending segment of the curve and $20 \%$, in average, in the descending segment.

Regarding the composite columns, satisfactory results were also obtained, due to the approximation between the experimental and numerical results curves. By analyzing, primarily, the axial force, it is noted that up to 50 minutes of fire, the numerical and experimental results are practically equal. From the 50-minute time point, the curves start to get distant, with the numerical model not representing the sudden force drop at the end of the test. This behavior can be attributed to the fact that in the numerical model the mechanical properties loss of the reinforcement by the fire action is not considered, so that the longitudinal bars can maintain their original resistance during the entire heating time. In addition, the axial displacements have a behavior quite similar to that observed in the forces. From Figure 5 and Figure 6 , it can be concluded that the numerical model can satisfactorily represent the thermal and thermo-structural behavior of the steel and steel and concrete composite columns tested and with similar characteristics.

\subsection{Parametric analysis}

From the numerical model validated for the steel and steel and concrete composite columns, the same modelling strategy was used to extend the analysis to other cases not addressed in the experimental program. As it is known in the scientific community, factors such as the restraint imposed by the structure concerning the column and the loading level significantly influence the displacements development and, consequently, the forces that develop during the heating.

It is also important to note that, although close, the heating curves obtained in the experimental analysis and used in the validation process do not match ISO 834 [19], recommended by ABNT NBR 14323 [1]. Besides, the coefficients used in the electric furnace test to represent the radiation and convection phenomena also do not coincide with those recommended by ABNT NBR 14323 [1].

Thus, in this item, the parametric analysis performed to evaluate the structural behavior of the steel and composite columns, composed of HEA 220 profile, is presented, considering the characteristics foreseen in ABNT NBR 14323 [1], in which the standard fire curve of ISO 834 [19] and emissivity factor equal to 0,7 were used, regardless of the material that constitutes the surface in contact with the heat. Among the parameters considered in the analysis, the column loading level, the relative axial restriction level imposed on the column and the global imperfection intensity in the middle of the span were varied.

As loading levels, values corresponding to $25 \%, 50 \%$ and $75 \%$ of the column load capacity at room temperature were adopted. The axial restraint level imposed on the column was considered relative, i.e., for the relation between the surrounding structure and the column stiffnesses $(375.1 \mathrm{kN} / \mathrm{mm}$ for the steel column and $1000 \mathrm{kN} / \mathrm{mm}$ for the composite column) values of $5 \%, 10 \%$ and $30 \%$ were adopted. Considering that the steel and partially encased composite columns have different load and stiffness capacities, the absolute value of the applied load and the surrounding structure stiffness were different

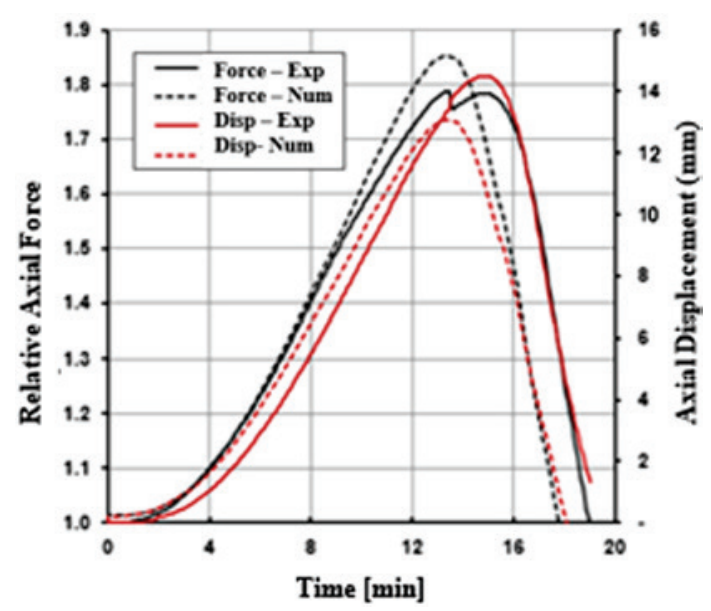

(a)

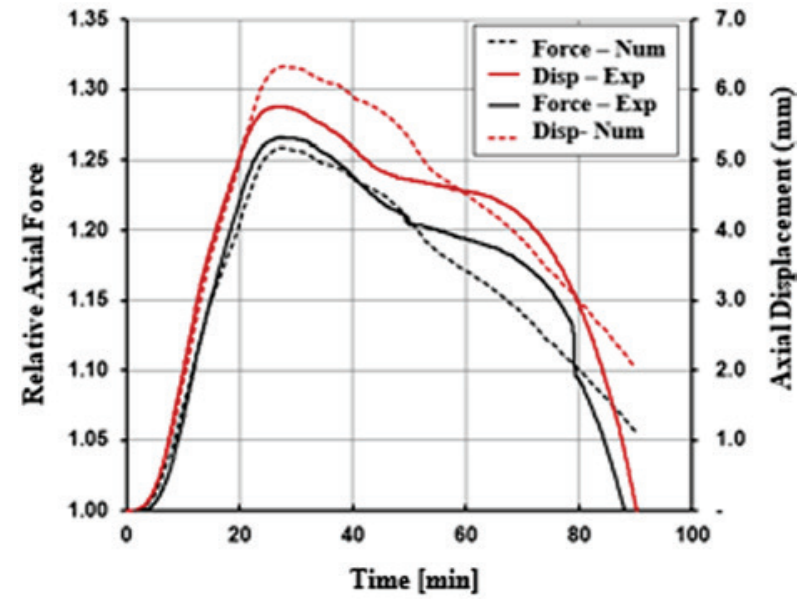

(b)

Figure 6

Comparison between the numerical and experimental results for the relative axial forces and axial displacements in the steel column (a) and steel and concrete composite columns (b) 
Table 3

Description of the parameters used in the parametric analysis

\begin{tabular}{|c|c|c|c|c|c|c|c|}
\hline \multirow{2}{*}{ Load ratio } & \multicolumn{2}{|c|}{$\begin{array}{c}\text { Absolute force } \\
{[\mathrm{kN}]}\end{array}$} & \multirow{2}{*}{$\begin{array}{c}\text { Relative } \\
\text { stiffness }\end{array}$} & \multicolumn{2}{|c|}{$\begin{array}{c}\text { Structure stiffness } \\
{[\mathrm{kN} / \mathrm{mm}]}\end{array}$} & \multirow{2}{*}{$\begin{array}{c}\text { Global } \\
\text { imperfection }\end{array}$} & $\begin{array}{l}\text { Value } \\
{[\mathrm{mm}]}\end{array}$ \\
\cline { 2 - 3 } & Steel & Composite & & Steel & Composite & & \\
\hline 0,25 & 390 & 625,5 & 0,05 & 18.76 & 50 & $\mathrm{~L} / 1500$ & 2 \\
\hline 0,50 & 780 & 1305 & 0,10 & 37.51 & 100 & $\mathrm{~L} / 1000$ & 3 \\
\hline 0,75 & 1170 & 1957,5 & 0,30 & 112.53 & 300 & $\mathrm{~L} / 500$ & 6 \\
\hline
\end{tabular}

for each case, as indicated in Table 3, however loading levels and relative stiffness fixed previously were respected. Finally, the last parameter considered refers to the overall imperfection intensity of the column, values of $L / 1500, L / 1000$ and $L / 500$ were chosen.

In the followed items will be presented how each of the varied parameters should influence the thermo-structural behavior of the columns in a fire situation, analyzing mainly the contribution in the relative axial forces development during the heating.

\subsubsection{Imperfection level influence}

The first parameter chosen for the complementary analysis evaluation is the level of global geometric imperfection adopted in the model. Hence, the variations of the relative axial force as a function of the heating time for the steel and composite columns, respectively, with 3 geometric imperfection levels adopted are presented in Figures $7 \mathrm{a}$ and $7 \mathrm{~b}$. Figure 7 shows the results for the models with load ratio of $75 \%$ and relative stiffness of $30 \%$, since for the other combinations the behavior was similar.

Also, in Figure 7 it can be observed, that for the steel or composite columns, there is a behavior change when the geometric imperfection is adopted or not in the model. In the steel column case, the critical time (time at which the axial force returns to its initial value after the peak) decreased from 9.7 to 8.7 minutes, considering the model without imperfection and the one with the imperfection of
$\mathrm{L} / 1500$, respectively. Still analyzing the steel column, increasing the imperfection from $L / 1500(2 \mathrm{~mm})$ to $L / 500(6 \mathrm{~mm})$, resulted in a decrease of only 0.2 minute at the critical time.

In the composite columns case, longer critical times were observed, mainly due to the fact that the concrete encasement made it difficult to heat the central parts of the section. For example, the profile web, which is protected by concrete, was heated mainly by conduction that starts at the heated profile flange. It should also be taken into account that the low thermal conductivity of the concrete causes it to heat at a much lower rate than the steel profile, resulting always in lower temperatures, especially in the innermost regions of the section. Owing to the fact that the concrete presents lower temperatures, the profile reinforcement also has lower temperatures and often does not present a decrease in its mechanical properties due to the temperature effects. Consequently, all of these combined factors, in general, ensure longer fire-resistant time for the steel composite columns partially encased with concrete.

Given that the imperfection level will not have a significant influence on the development of the relative axial forces, the other analysis will be carried out always considering the models with global imperfection of L/1500.

\subsubsection{Loading level influence}

In the next step, the results are analyzed considering the influence

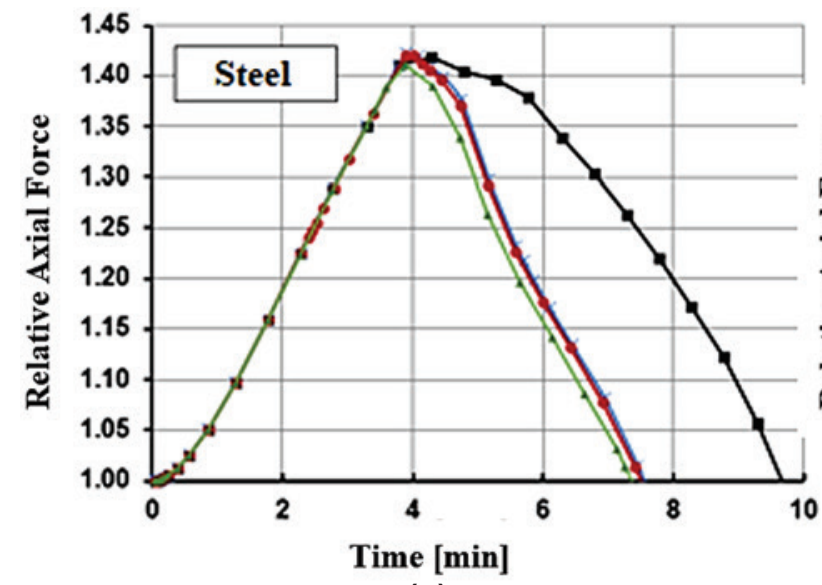

(a)

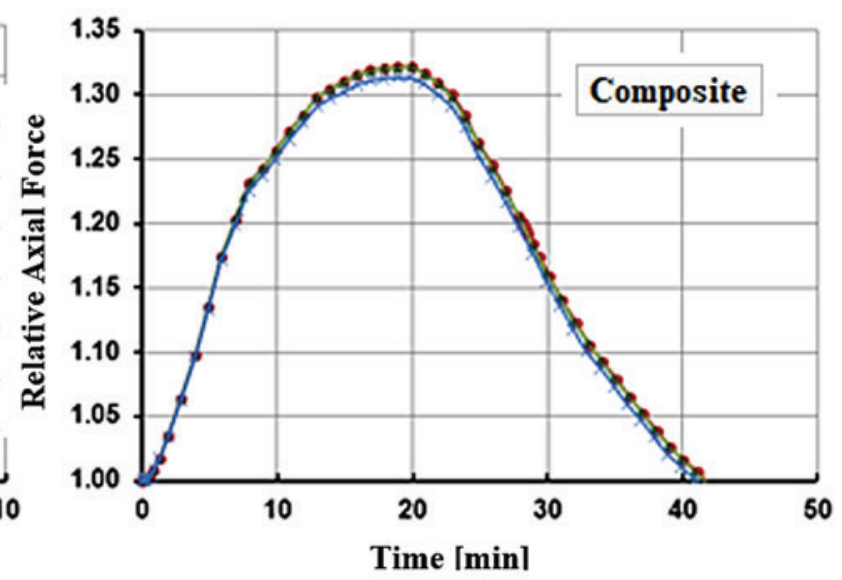

(b)

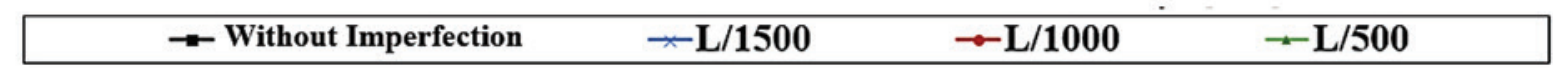

\section{Figure 7}

Variation of the relative axial force for different values of geometric imperfection in models with load ratio of $75 \%$ and relative stiffness of $30 \%$ in (a) steel and (b) composite columns 


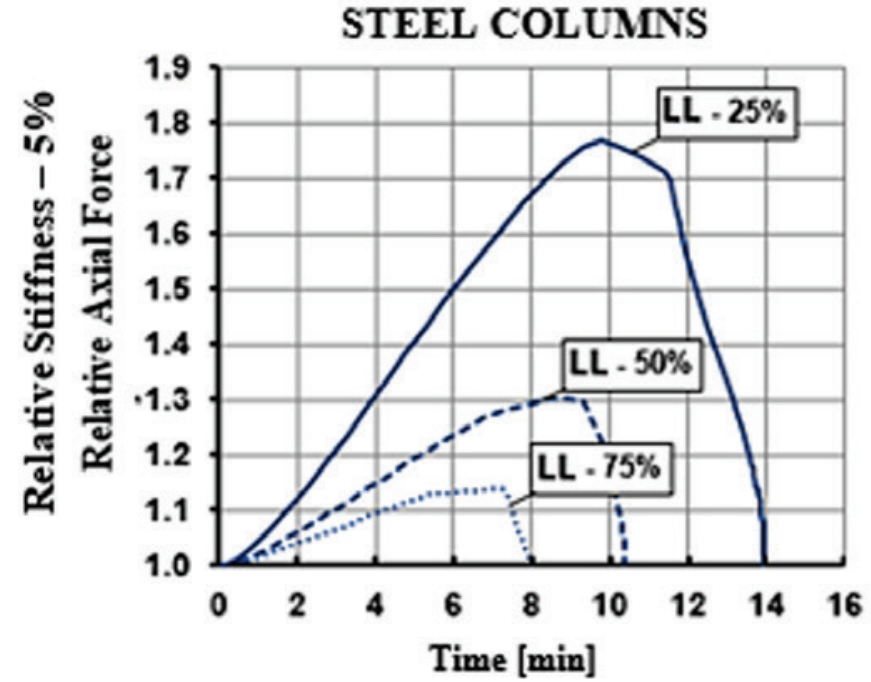

(a)

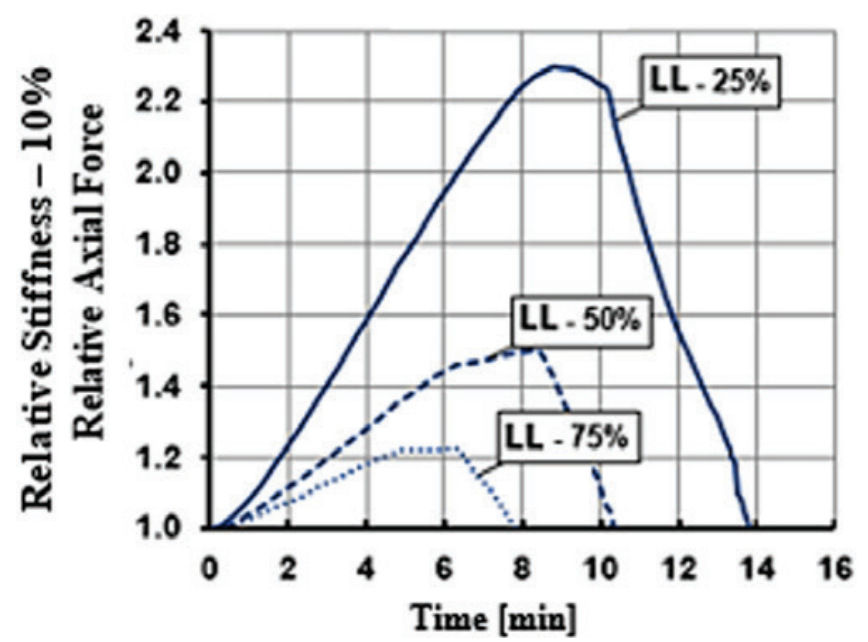

(c)

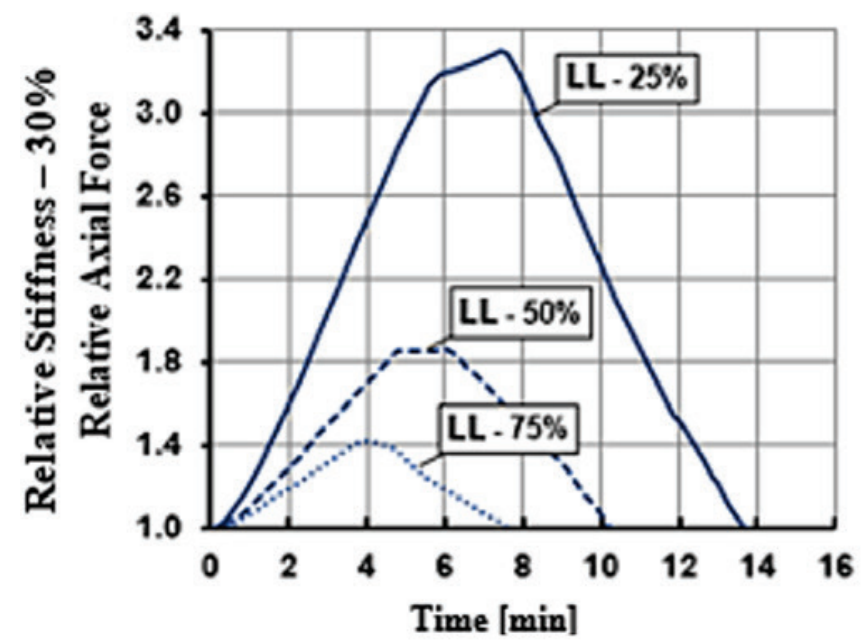

(e)

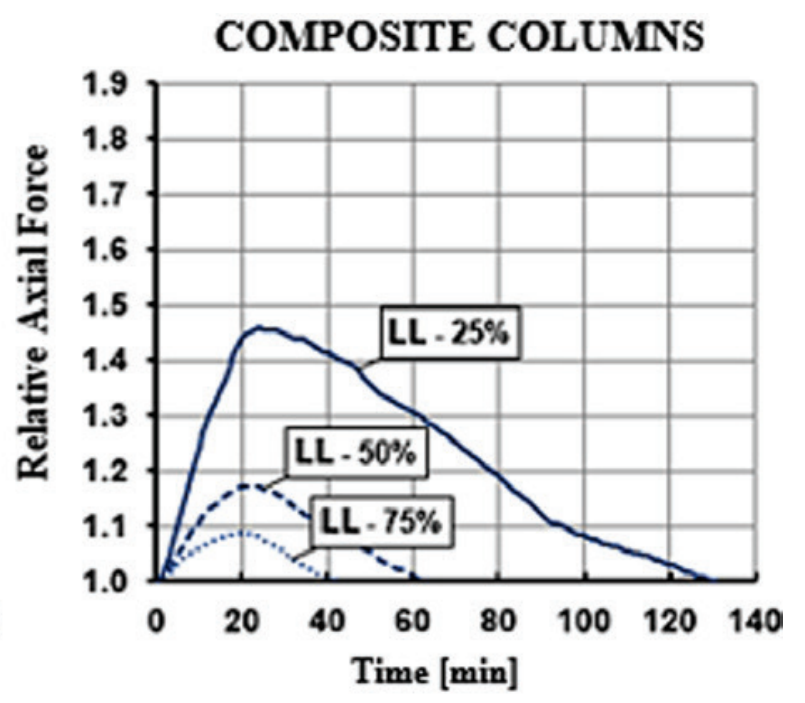

(b)

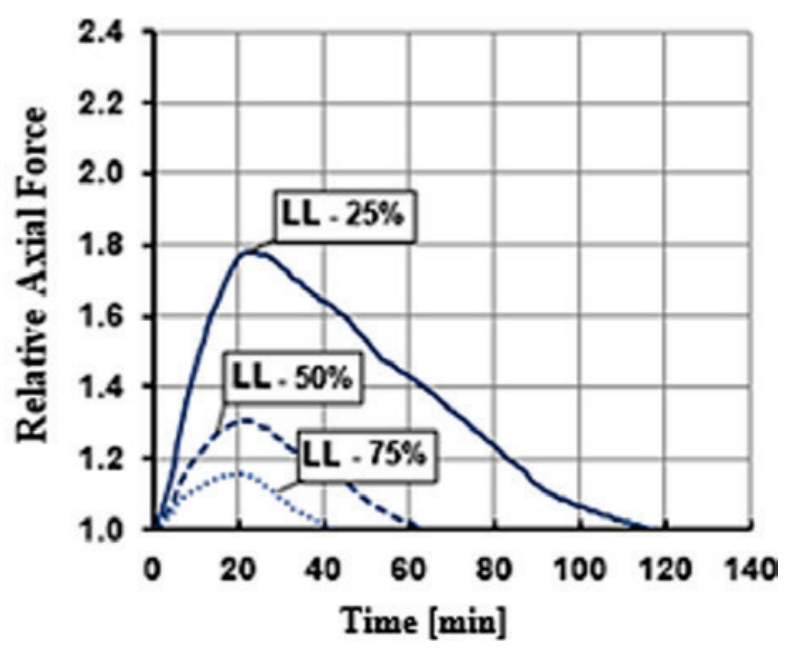

(d)

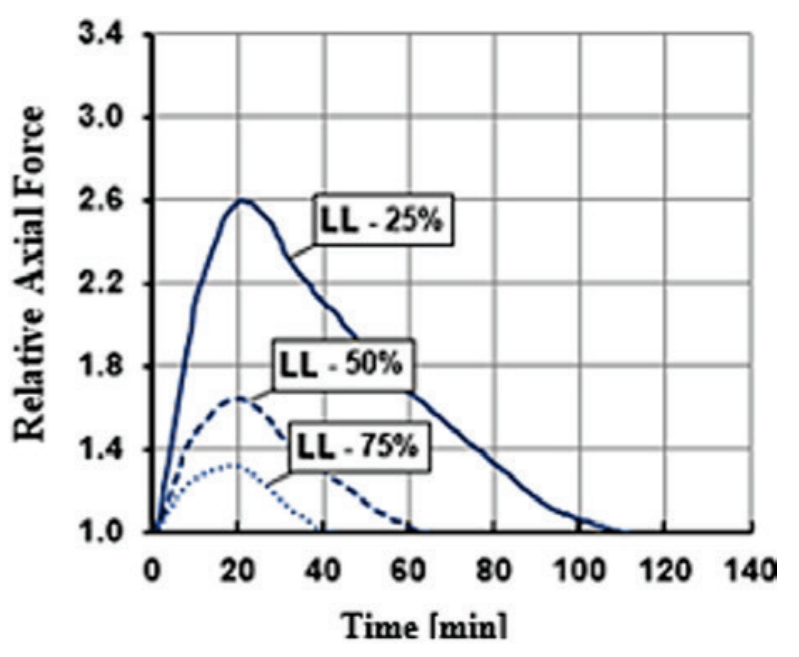

(f)

Figure 8

Influence of load level variation on the development of relative axial forces for steel and composite columns 
of the loading level (LL) applied in the model. Figures 8 a to $8 \mathrm{f}$ show the evolution curves of the relative axial force for all processed models. In each one of them, a given level of relative axial stiffness is considered fixed, separately for steel and composite columns. Generally speaking, the higher the load ratio considered before the heating, the lower the relative axial force. This fact is confirmed once it is possible for the column to increase its axial force considerably until its load capacity, represented by the curve peak. Evaluating initially Figure $8 \mathrm{a}$, which indicates the results for the steel columns with $5 \%$ relative stiffness, the maximum relative axial forces for the $25 \%, 50 \%$ and $75 \%$ load ratios were equal to 1.77 , 1.30 and 1.14 , respectively.

In addition, for the steel columns such peaks were observed at different times, the lower the load ratio the more time was necessary to reach the peak. This finding is justified, since the increase of force occurs gradually with the increase of temperature and the restriction of the thermal expansions. Thus, the lower the load applied to the column at the start of the heating, the more axial force it will be able to absorb and, consequently, the more time it will required to reach its load capacity.

After the peak, the steel columns show a sharper drop than the composite ones. As for the peak values, the critical times observed are always larger the lower the load ratio used. Still in Figure 8 a case, the critical times were 14, 10, 2 and 8 minutes for the loading factors of $25 \%, 50 \%$ and $75 \%$, respectively. In section 4.2.4 will be presented a summary with all the critical times of the performed models.

Observing the behavior change of the curves with different load ratios, but with higher stiffness levels (Figure $8 \mathrm{c}$ and $8 \mathrm{e}$ ), it is noted that the axial force behavior is similar to that discussed for Figure 7a. However, higher stiffness levels resulted in higher relative axial forces developed in the column, as can be seen from the difference between the results of Figures $8 \mathrm{a}, 8 \mathrm{c}$ and $8 \mathrm{e}$. More information about the behavior for different stiffness levels will be commented in the item 4.2.3.

For the composite columns shown in Figure $8 \mathrm{~b}, 8 \mathrm{~d}$ and $8 \mathrm{f}$, a higher critical temperature was identified when compared to the steel columns, due to the fact that the concrete encasement decreased the heating rate of the steel profile. Comparing Figures $8 \mathrm{a}$ and $8 \mathrm{~b}$, it can be observed that for the case with $25 \%$ load ratio and $5 \%$ relative stiffness, the critical time went from 14 minutes in the steel column to 130 minutes in the composite column. In all cases it was observed that the composite column, when compared in a same loading and stiffness level, presented critical time greater than the steel one.

Another important feature to be observed in the composite columns case is that, regardless of the load and stiffness level used, the time at which the peak force is reached was always the same. Besides, the post-peak behavior is much more ductile, with the axial force falling slowly. Finally, we look at the intensity of the maximum relative axial forces found in the composite column, which are smaller than those of the steel columns, when compared to a column with same stiffness and load ratio.

The fact that the relative axial forces for the composite columns have lower values is related to the initial force intensities applied before the heating, which in turn are the divisors for the Relative Axial Force calculation and are higher than in the steel columns case. Hence, the absolute force acting on the column during heating may, in many cases, be higher in the composite column than in the steel one, even having a lower relative axial force. In any case, the analysis by relative force is quite significant in order to compare the thermo-structural behavior between elements with different characteristics, as well as to verify the amount of additional loading that these elements will be subjected to during the fire.

\subsubsection{Axial restraint level influence}

In a similar way to what was done in item 4.2.2, in Figures 9a to $9 f$ are shown the variation of the relative axial force being kept a loading level, separately for the steel and composite columns.

Among the main considerations that may be mentioned, the most notable is that, regardless of the stiffness level of the surrounding structure, the column critical time will be practically the same when considering the same loading level. The largest difference between critical times was observed in the composite columns with load ratio of $25 \%$ (Figure $9 \mathrm{~b}$ ), being approximately 20 minutes between the models with higher and lower stiffness of the surrounding structure. In other cases, this difference was less than 1 minute. This finding can be observed in both steel and composite columns, as can be seen in each of Figures 9a to $9 f$.

This is explained by the fact that the heating curve for all cases was the same. This way, by taking Figure $9 \mathrm{~d}$ as an example, at 63 minutes (instant when the axial force returns to its initial value), the thermal field established in the sections, regardless of the stiffness level considered in the spring, is the same. Therefore, the column resistant capacity, which is directly affected by the mechanical properties reduction by this temperature level, will be equal to the force acting on the section which, in turn, corresponds to the applied load ratio.

Hence, what will be changed for each loading level will be the instant that the heating generates a thermal field that reduces the column resistant capacity to a value equal to the applied load. As the heating is the same in all cases, this instant is practically coincident regardless of the stiffness considered in the spring.

With Figure 9 it is possible to note more clearly how the change in the stiffness of the surrounding structure to the column will affect the strength of the force generated in the column, being that the greater the stiffness the larger the thermal expansion constraint, thus generating a bigger effort on the columns.

\subsubsection{Results summary}

As a way of summarizing the results presented throughout this paper, for each of the models considered the time in which the peak value of the relative axial force is reached, the critical time and the web and flange temperature at the instant of critical time are presented in Table 4. In that table, the results are presented considering the models with the least imperfection (L/1500), since for the other values the results did not change significantly.

\section{Conclusions}

With the numerical models developed with the ABAQUS computational package, it can be concluded that the numerical strategy 


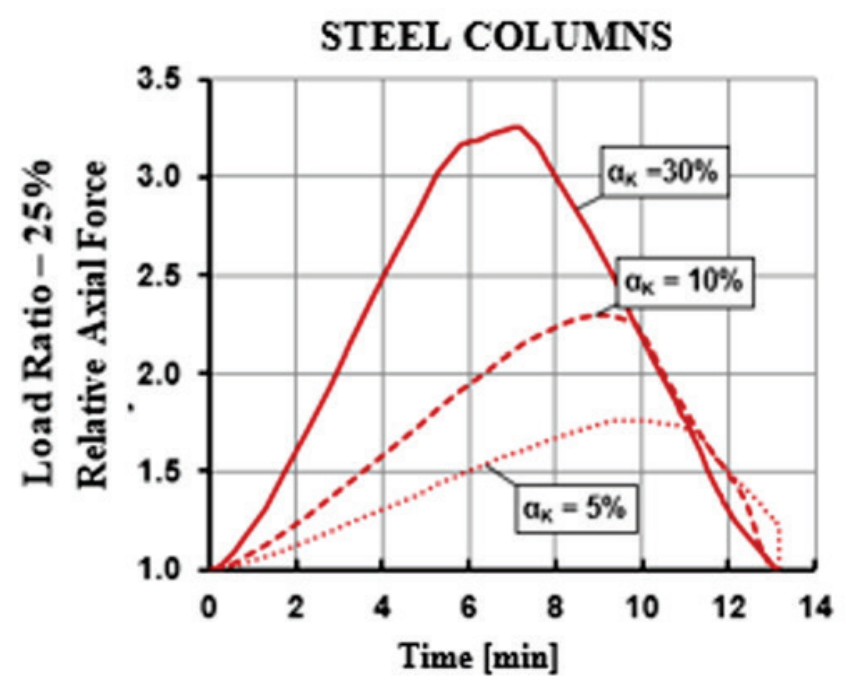

(a)

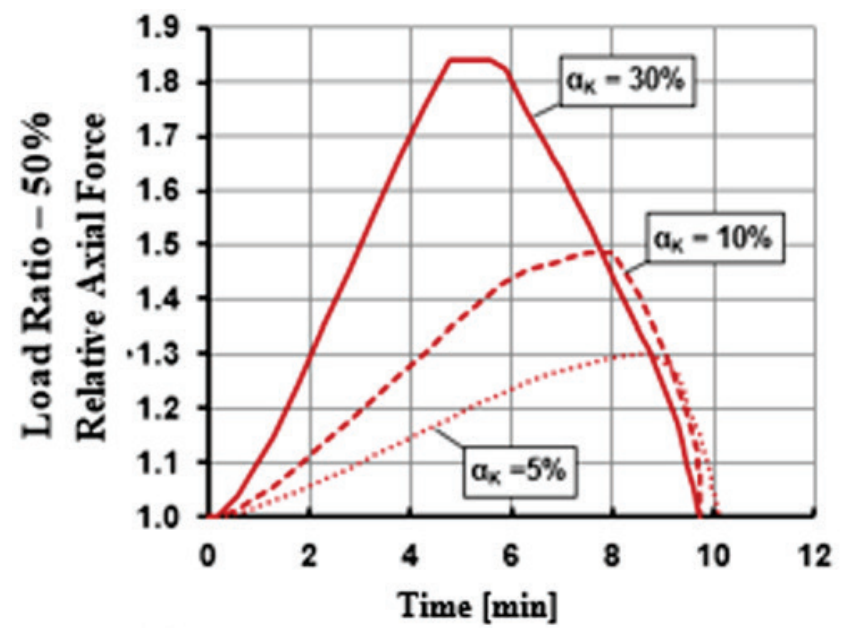

(c)

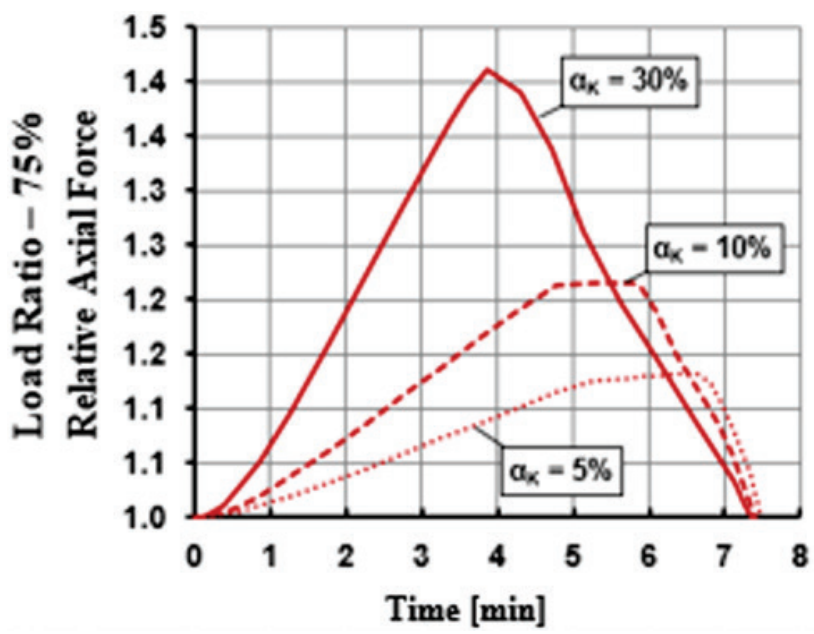

(e)

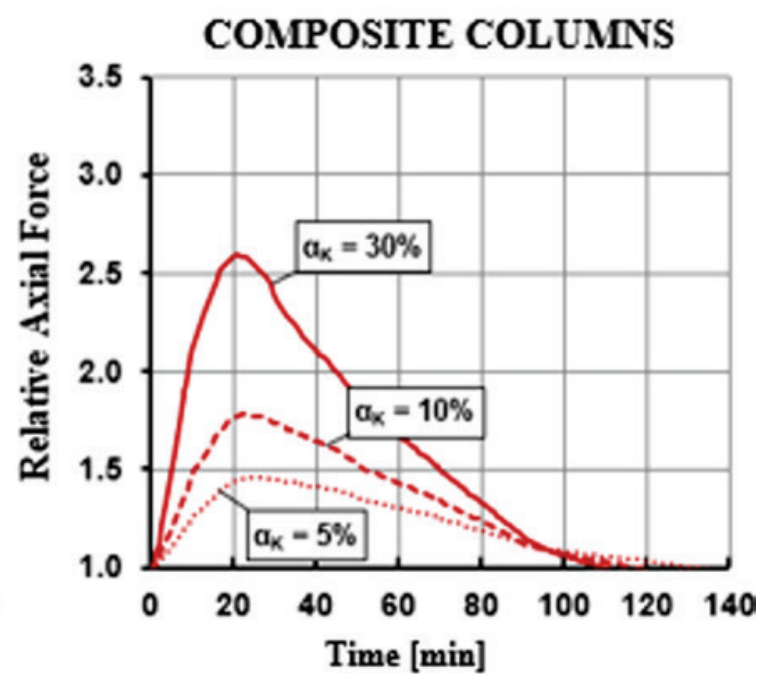

(b)

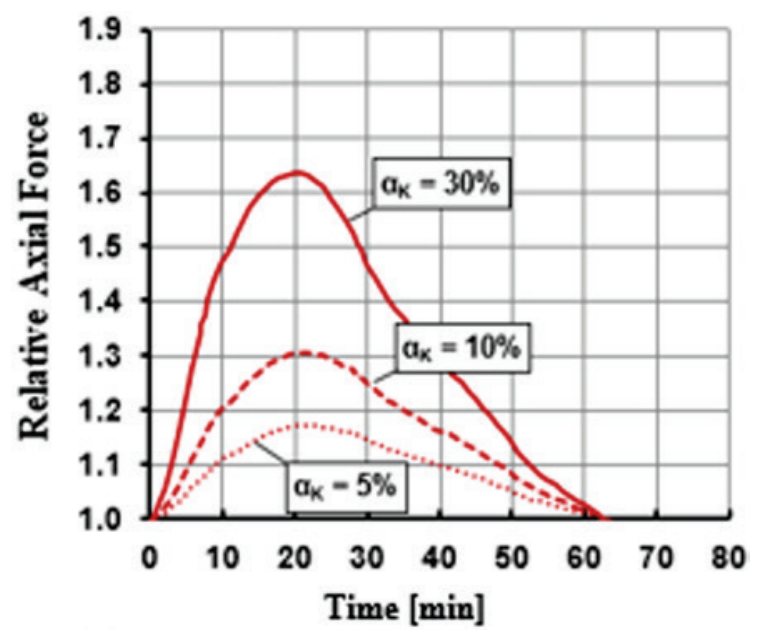

(d)

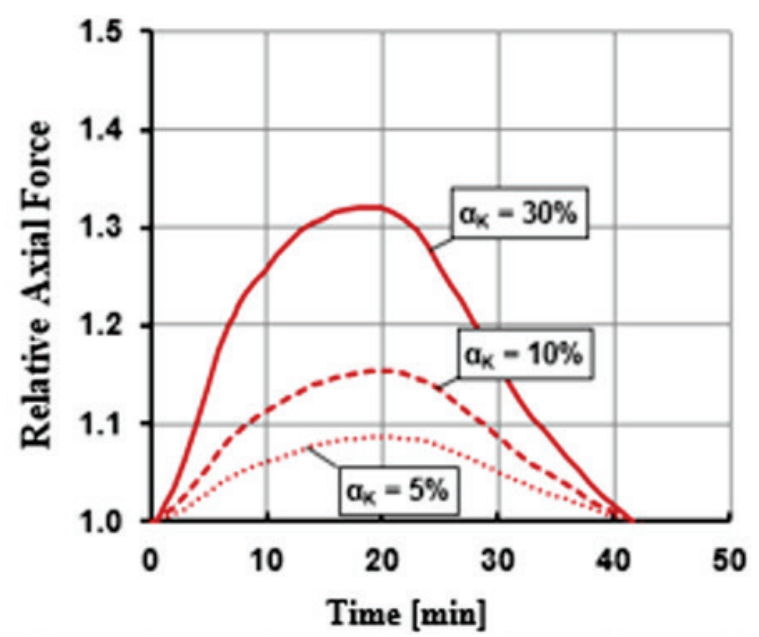

(f)

Figure 9

Influence of the axial stiffness variation of the surrounding structure in the development of the relative axial forces for the steel and composite columns 
Table 4

Results summary of the parametric analysis models for steel and steel and concrete composite columns

\begin{tabular}{|c|c|c|c|c|c|c|c|c|c|}
\hline \multirow{2}{*}{ Load ratio } & \multirow{2}{*}{$\begin{array}{c}\text { Relative } \\
\text { stiffness }\end{array}$} & \multicolumn{2}{|c|}{$\begin{array}{c}\text { Peak time } \\
\text { [min] }\end{array}$} & \multicolumn{2}{c|}{$\begin{array}{c}\text { Critical time } \\
\text { [min] }\end{array}$} & \multicolumn{2}{c|}{$\begin{array}{c}\text { Flange temperature } \\
{\left[{ }^{\circ} \mathbf{C}\right]}\end{array}$} & \multicolumn{2}{c|}{$\begin{array}{c}\text { Web temperature } \\
{\left[{ }^{\circ} \mathbf{C}\right]}\end{array}$} \\
\cline { 3 - 10 } & & Steel & Composite & Steel & Composite & Steel & Composite & Steel & Composite \\
\hline 0,25 & 5 & 9,78 & 26,2 & 13,9 & 130,5 & 649,1 & 1053,0 & 685,2 & 780,0 \\
\hline 0,25 & 10 & 9,30 & 24,9 & 13,8 & 116,5 & 646,8 & 1034,0 & 683,6 & 731,7 \\
\hline 0,25 & 30 & 7,42 & 21,9 & 13,7 & 109,0 & 643,5 & 1023,0 & 681,1 & 707,3 \\
\hline 0,50 & 5 & 9,30 & 22,8 & 10,4 & 62,8 & 584,0 & 924,4 & 606,9 & 465,6 \\
\hline 0,50 & 10 & 8,41 & 21,9 & 10,3 & 63,0 & 547,7 & 924,9 & 606,6 & 466,7 \\
\hline 0,50 & 30 & 6,14 & 20,8 & 10,2 & 62,9 & 543,3 & 924,3 & 603,1 & 465,9 \\
\hline 0,75 & 5 & 7,26 & 20,9 & 8,0 & 42,1 & 446,2 & 820,3 & 520,8 & 304,5 \\
\hline 0,75 & 10 & 6,40 & 20,9 & 7,8 & 41,9 & 438,1 & 818,8 & 513,4 & 302,8 \\
\hline 0,75 & 30 & 4,09 & 20,9 & 7,6 & 40,9 & 425,9 & 810,7 & 502,4 & 293,8 \\
\hline
\end{tabular}

can represent well the thermal and thermo-structural behavior of steel and steel and concrete composite columns considering the fire acting on all faces. However, the use of the values for the thermal emissivity presented in ABNT NBR 14323 [1] did not present coherent results during the model validation process, being necessary to change it to represent the real test condition in an electric furnace. Regarding the behavior of the steel and composite columns restricted to thermal elongation at their ends, when exposed to fire on all faces, it is possible to conclude that both exhibit a similar behavior, but with critical times of fire resistance quite different. In both cases, there is a gradual increase of the axial force to the peak instant, followed by the decrease of the force until the moment when it returns to its initial test value. Nevertheless, the composite columns presented critical times up to 10 times greater than the steel ones when considered the same stiffness level and load ratio. The highest fire resistance of the composite columns is mainly due to the concrete encasement, which reduces the web temperature of the steel profile, allowing it to absorb the section stresses for longer. It should be noted that the profile flanges presented higher temperatures at the test end in the composite columns case.

Analyzing the results obtained by the parametric analysis, it can conclude that the geometric imperfection did not significantly modify the thermo-structural behavior of the columns. However, the load ratio was the parameter that most influenced the fire resistance of the column, so that the higher the load applied, the lower the critical time obtained. On the other hand, the maximum relative force reached during the test was higher in cases where less load was applied, since the increase of force compared to the applied load is greater in these cases. Finally, the restraint level to deformations at the ends does not interfere significantly in the column critical time, but in the maximum axial force reached during the test, so that the higher the restriction level the greater the forces obtained.

\section{Acknowledgments}

The authors of this paper are grateful to the São Paulo Research Foundation (FAPESP), the National Council for Scientific and Technological Development (CNPq), the Coordination for the Improvement of Higher Education Personnel (CAPES) and the Department of Structural Engineering of São Carlos School of Engi-
neering/USP for the support directed to the accomplishment of the present work.

\section{References}

[1] ABNT. ASSOCIAÇÃO BRASILEIRA DE NORMAS TÉCNICAS. Projeto de estruturas de aço e de estruturas mistas de aço e concreto de edifícios em situação de incêndio. - NBR 14323, Rio de Janeiro, 2013.

[2] EUROCODE. EUROPEAN COMMITTEE FOR STANDARDIZATION. Eurocode 3 - Design of Steel Structures. Part 1-2: General rules - Structural Fire Design. Brussels, 2005

[3] EUROCODE. EUROPEAN COMMITTEE FOR STANDARDIZATION. Eurocode 4 - Design of composite steel and concrete structures. Part 1-2: General rules- Structural Fire Design. Brussels, 2005.

[4] BUBACH, C.R. Pilares de aço com restrição axial e rotacional em situação de incêndio, Espírito Santos, 2016, Dissertação (Mestrado em Engenharia de Estruturas) - Universidade Federal do Espírito Santo, Vitória, 194 p.

[5] NEVES, I.C. The critical temperature of steel columns with restrained thermal elongation. Fire Safety Journal, v. 24, n. 3, 1995; p. 211-227.

[6] AASEN, B. An experimental study on steel column behaviour at elevated temperatures. Division of Steel Structures, Norwegian Institute of Technology, University Trondheim, Trondheim, Norway, 1985.

[7] ALI, F.A. et al. The effect of axial restraint on the fire resistance of steel columns. Journal of Constructional Steel Research, v. 46, 1998; p. 305-306.

[8] ALI, F.A. et al. The effect of axial restraint on the fire resistance of steel columns. Journal of Constructional Steel Research, v. 46, 1998; p. 305-306.

[9] NEVES, I.C.; VALENTE, J.C.; RODRIGUES, J.P.C. Thermal restraint and fire resistance of columns. Fire Safety Journal, v. 37, n. 8, 2002; p. 753-771.

[10] CORREIA, A.J.P.M.; RODRIGUES, J.P.C. Fire resistance of steel columns with restrained thermal elongation. Fire Safety Journal, v. 50, 2012; p. 1-11.

[11] CORREIA, A.J.P.M.; RODRIGUES, J.P.C.; GOMES, F.C.T. A simplified calculation method for fire design of steel columns 
with restrained thermal elongation. Computers \& Structures, v. 116, 2013; p. 20-34.

[12] HUANG, Z.F.; TAN, K.H.; PHNG, G.H. Axial restraint effects on the fire resistance of composite columns encasement Isection steel. Journal of Constructional Steel Research, v. 63, n. 4, 2007; p. 437-447.

[13] HUANG, Z.F. et al. Fire resistance of composite columns with embedded I-section steel - Effects of section size and load ratio. Journal of Constructional Steel Research, v. 64, n. 3, 2008; p. 312-325.

[14] CORREIA, A.J.P.M.; RODRIGUES, J.P.C. Fire resistance of partially encased steel columns with restrained thermal elongation. Journal of Constructional Steel Research, v. 67, n. 4, 2011; p. 593-601.

[15] ELLOBODY, E. A consistent nonlinear approach for analysing steel, cold-formed steel, stainless steel and composite columns at ambient and fire conditions. Thin-Walled Structures, v. 68, 2013; p.1-17.

[16] HAN, L.H.; TAN, Q.H.; SONG, T.Y. Fire performance of steel reinforced concrete columns. Journal of Structural Engineering, v. 141, n. 4, 2015; p. 04014128.

[17] HAN, L.H. et al. Performance of Steel-Reinforced Concrete Column after Exposure to Fire: FEA Model and Experiments. Journal of Structural Engineering, 2016; p. 04016055.

[18] ROCHA, F.M. Pilares de aço e misto de aço e concreto inseridos em paredes em situação de incêndio, São Paulo, 2016, Tese (Doutorado em Engenharia de Estruturas) - Escola de Engenharia de São Carlos, Universidade de São Paulo, São Carlos, $256 \mathrm{p}$.

[19] ISO. INTERNATIONAL STANDARD. Fire-resistance tests - Elements of building construct - Part 1: General requirements. - ISO 834, 1999.

[20] ABNT. ASSOCIAÇÃO BRASILEIRA DE NORMAS TÉCNICAS. Projeto de estruturas de concreto em situação de incêndio - procedimento. - NBR 15200, Rio de Janeiro, 2012. 